\title{
Kierkegaard e a transformação do sujeito em si mesmo entre a vertigem da liberdade e o paradoxo absoluto da fé
}

\author{
Luiz Carlos Mariano da Rosa*
}

\section{RESUMO}

Atribuindo à ironia a possibilidade de exercício e desenvolvimento da liberdade subjetiva, Kierkegaard sublinha a negatividade absoluta como característica do referido processo em Sócrates, convergindo para assinalar o absoluto e irredutivel valor do indivíduo em um movimento que implica o início absoluto da vida pessoal entre criarse (poeticamente) e deixar-se criar (poeticamente). Dessa forma, contrapondo-se à dissolução da existência humana nas fronteiras da pura conceituação intelectual, Kierkegaard assinala a tensão inaplacável entre existência e transcendência em um movimento que implica a interioridade e guarda correspondência com a necessidade de tornar-se subjetivo, tendo em vista a perspectiva que defende que a verdade consiste na transformação do sujeito em si mesmo entre a vertigem da liberdade e o paradoxo da fé em um processo que encerra angústia e desespero e converge para a transição do ético ao religioso.

Palavras-chave: Kierkegaard; Sócrates; ironia; angústia; subjetividade; fé.

\section{KIERKEGAARD AND THE TRANSFORMATION OF THE SUBJECT IN HIMSELF BETWEEN THE VERTIGO OF LIBERTY AND THE ABSOLUTE PARADOX OF FAITH}

\footnotetext{
ABSTRACT

Attributing to irony the possibility of exercise and development of subjective freedom, Kierkegaard emphasizes absolute negativity as characteristic of the said process in Socrates, converging to point out the absolute and irreducible value of the individual in a movement that

* Pós-graduando em Ciências da Religião pela Universidade Cândido Mendes (UCAM RJ). Professor-pesquisador e filósofo-educador no Espaço Politikón Zôon - Educação, Arte e Cultura. E.mail: marianodarosaletras@gmail.com.
} 
implies the absolute beginning of the personal life between to create oneself (poetically) and let yourself be created (poetically). As opposed to the dissolution of human existence on the frontiers of pure intellectual conceptualization, Kierkegaard points out the unreliable tension between existence and transcendence in a movement that implies interiority and is in keeping with the need to become subjective, in view of the a perspective that holds that truth consists in the transformation of the subject into itself between the vertigo of freedom and the paradox of faith in a process that contains anguish and despair and converges for the transition from ethical to religious.

Keywords: Kierkegaard; Socrates; irony; anguish; subjectivity; faith.

\section{Aspectos Introdutórios}

Opondo-se ao racionalismo característico do Iluminismo, o Romantismo atribui relevância à imaginação e à intuição, à espontaneidade e à paixão, ao sentimento e à emoção, em um movimento que impõe centralidade ao indivíduo e enfatiza a relação envolvendo a sua subjetividade e o mundo objetivo e tende a circunscrever a possibilidade do saber ao conhecimento que a consciência tem de si, segundo a perspectiva de Schelling, principal representante do romantismo filosófico na Alemanha, cujo pensamento instaura a identidade entre a consciência e a natureza em um processo que converge para a sua realização no Absoluto e encerra a capacidade de superar a oposição sujeito/objeto.

Se o Iluminismo caracteriza-se pela defesa da ciência e da racionalidade crítica em oposição à fé, à superstição e ao dogma religioso, ao arcabouço de valores, práticas e condutas da ordem instituída em um processo que atribui à razão primazia em relação a todas as faculdades humanas, circunscrevendo as suas fronteiras a possibilidade do conhecimento, o Romantismo tende a exaltar a singularidade e a originalidade do indivíduo em um movimento que converge para a emergência da individualidade, tendo em vista a perspectiva que encerra a concepção de que a manifestação do eu verdadeiro guarda correspondência com a esfera que envolve o sentimento e a emoção, na medida em que contrapõe-se à abstração e à esterilidade de uma construção que demanda que o indivíduo venha 
abstrair-se de si mesmo para alcançar uma determinada compreensão, o que implica um resultado que depende do conjunto de propriedades da razão que, sendo universais e idênticas em todo indivíduo, sobrepõese a sua especificidade e converge para a sua supressão enquanto tal.

A superação dos limites da razão, eis o que se impõe ao Romantismo, que valoriza a imaginação e a intuição, a espontaneidade e a paixão, o sentimento e a emoção, como um conjunto cuja singularidade, especificidade, originalidade, converge para possibilitar a emergência do eu verdadeiro e o exercício de uma subjetividade que se contrapõe aos valores, práticas e condutas da ordem instituída através de um processo que utiliza a ironia como recurso estratégico que torna independente o agente em um movimento de oposição ao modus vivendi da sociedade que tende à desestabilização de sua vida histórico-cultural e a negação da influência dos costumes ou tradições que, condicionando atitudes e comportamentos, impedem a realização da liberdade subjetiva.

Se para o Romantismo a ironia (ironia trágica) emerge como um jogo dialético que envolve zombaria e seriedade, configurando a impossibilidade de que a consciência infinita confira condição fundamental às formas da sua produção (dentre as quais a natureza, a arte, assim como o próprio eu) em um processo que tende a impor princípios que supostamente determinam o mundo, na medida em que tais manifestações permanecem relegadas ao âmbito da impermanência e da provisoriedade, destinadas ao movimento de dissolução que a sua transformação implica, atribuindo à ironia a possibilidade de exercício e desenvolvimento da liberdade subjetiva, Kierkegaard sublinha a negatividade absoluta como característica do referido processo em Sócrates, o que implica a construção de uma perspectiva que converge para as fronteiras que encerram relativismo e niilismo e capacita o indivíduo a buscar a verdade subjetivamente. Dessa forma, contrapondose à interpretação de Hegel $^{1}$ concernente à ironia socrática em face

1 Caracterizando-se como a consciência da subjetividade absoluta em um processo que se lhe atribui condição de primazia completa em relação a totalidade que, encerrando as outras coisas, é relegada ao âmbito do nada, a ironia emerge do pensamento de Fichte, convergindo para as fronteiras que implicam a consciência do absoluto arbitrio de tal subjetividade, segundo a interpretação de Schlegel. Eis o que Hegel assinala: "Consiste ela no seguinte: conhecer sem dúvida a objetividade moral, mas em vez de mergulhar no 
da ênfase atribuída ao conceito abstrato em detrimento do fenômeno histórico concreto, Kierkegaard correlaciona ambos - conceito abstrato (aspecto filosófico) e fenômeno histórico concreto (aspecto empírico) - em um movimento dialético que tende à negatividade absoluta corporificada pela aporia ${ }^{2}$ em um processo que, sobrepondo-se à verdade, converge para a desestabilização do arcabouço de valores, práticas e condutas da ordem instituída, encerrando como objetivo a busca do bem e a elaboração do seu conceito.

Nesta perspectiva, se a modernidade tende a diluir o indivíduo e a sua subjetividade em uma estrutura de produção industrial, alcança relevância a perspectiva de Kierkegaard, que recusa a atribuição da condição de bem absoluto ao saber em um movimento que guarda correspondência com a busca não da verdade mas de um centro para a vida, na medida em que defende que apenas a subjetividade é verdade e que o seu elemento é a interioridade através de uma construção que tende à incerteza objetiva, haja vista a concepção acerca da incapacidade do pensamento e da impotência da linguagem diante da verdade subjetiva, o que implica a questão do caráter inapreensível do mundo subjetivo ou da possibilidade ou não de transposição da sua realidade para o mundo objetivo.

que ela tem de sério e de agir tomando-a como princípio, esquecendo e renunciando a si, manter pelo contrário a distância da relação com ela e conhecer-se como o que quer e decidir isto ou aquilo e poder também decidir de outro modo. Admitis vós uma lei, efetiva e honestamente, como existente em si e para si, também eu me encontro no plano e nos quadros de tal lei, mas como estou ainda longe dela posso ladeá-la e entendê-la como quiser. O que está em primeiro lugar não é a coisa, mas eu próprio: sou eu o soberano senhor não só da coisa como da lei, dela disponho como entender e, naquele estado de consciência irônico em que deixo afundar-se o que há de mais elevado, só de mim mesmo me ocupo." (HEGEL, 1997, § 140, p. 137)

2 Longe de consistir em um estado subjetivo de incerteza, a aporia representa a dificuldade, o impasse inerente a um raciocínio em um processo que pretende a expressão da essência ou da natureza de algo e implica uma tensão lógica que converge para a indeterminação e encerra uma dúvida objetiva, perfazendo um movimento que guarda correspondência com o princípio socrático baseado na máxima "só sei que nada sei", que encerra a consciência da sua ignorância e detém uma sabedoria puramente negativa. Assim, diante da necessidade de uma construção positiva capaz de encerrar o sentido de algo, exprimindo a sua essência ou natureza, Sócrates impõe uma crítica interrogativa que tende à problematização dos fundamentos de um conceito ou uma asserção por intermédio de uma relação dialógica em um processo que implica um intercâmbio sistemático de afirmações e negações que põe em evidência a contradição e converge para um resultado puramente negativo. 
Dessa forma, o artigo se detém em um processo que torna fundamental a ironia que sob a acepção de negatividade absoluta infinita converge para a alienação do indivíduo em relação à existência e a alienação da existência em relação ao indivíduo em uma experiência que encerra a simbolização da tensão entre valores/cultura e o indivíduo e que se circunscreve à negação de toda a realidade, convergindo para assinalar o absoluto e irredutivel valor do indivíduo em um movimento que implica a transformação do sujeito em si mesmo entre a vertigem da liberdade e o paradoxo da fé.

\section{Ironia e negatividade absoluta: a ironia como início absoluto da vida pessoal entre criar-se (poeticamente) e deixar-se criar (poeticamente)}

Baseado em uma concepção do saber como interioridade, tendo em vista o seu caráter essencialmente reflexivo em uma construção que converge para a descoberta do universal da ética em si próprio, Sócrates afirma a impossibilidade de que a verdade seja transmitida a partir da exterioridade, na medida em que concebe a dimensão externa como parte constitutiva da sua interioridade e pressupõe que a verdade objetiva exige o exercício da racionalidade e da reflexão crítica, o que implica uma unidade envolvendo o universal interior e o universal exterior em um processo que atribui à esfera subjetiva a condição que encerra a interioridade universal do pensamento, convergindo para as fronteiras que encerram a primazia do indivíduo e da sua liberdade subjetiva em relação à coletividade e ao contexto histórico-cultural e ao seu movimento de imposição de valores, práticas e condutas que se sobrepõe ao sujeito e impede a manifestação de sua individualidade.

O ponto de vista de Sócrates é pois o da subjetividade, da interioridade, que se reflete em si mesma e em sua relação para consigo mesma dissolve e volatiliza o subsistente nas ondas do pensamento, que se avolumam sobre ele e o varrem para longe, enquanto a própria subjetividade novamente afunda, refluindo para o pensamento. No lugar daquele pudor que poderosa, mas misteriosamente mantinha o indivíduo nas articulações do Estado, aparece doravante a decisão e a certeza interior da subjetividade. (KIERKEGAARD, 1991, p. 131, grifos meus) 
Perfazendo um movimento que guarda correspondência com o princípio "só sei que nada sei", que encerra a consciência da sua ignorância e detém uma sabedoria puramente negativa, Sócrates instaura a crítica interrogativa como um princípio metodológico baseado na intersubjetividade e na virtude heurística do diálogo, que implica um processo que põe em evidência a contradição e converge para um resultado puramente negativo. Dessa forma, objetivando a revelação ao interlocutor de nada que porventura já não esteja em sua interioridade em um processo que escapa à pretensão de impor através de um fenômeno externo tudo aquilo que o próprio sujeito não saiba ou encerre em seu íntimo, o diálogo socrático converge para um movimento de iluminação que emerge em face da instauração de uma diligência reflexiva que tende a procurar a verdade em seu âmago, em sua subjetividade e pelas suas próprias capacidades, encerrando uma operação racional que visa a libertação do homem da ignorância e implica o alcance do saber verdadeiro, que se sobrepõe às opiniões particulares e ao condicionamento das paixões e concorre para a descoberta do universal em uma construção que tem como fim o aperfeiçoamento da alma e do cidadão, constituindo-se uma prática que, segundo Kierkegaard, corresponde ao amor cristão, visto que demanda uma atitude de desinteresse e uma participação anônima do agente em um movimento que encerra autossacrifício em função da necessidade envolvendo a possibilidade de independência do próximo e da sua "libertação".

Nesta perspectiva, baseado no paradigma socrático, Kierkegaard se opõe às concepções de Cristianismo instituídas pela igreja através do pensamento de teólogos e filósofos acadêmicos, defendendo que a verdade demanda uma experiência de apropriação $o^{3}$ que implica a condição que envolve a paixão da interioridade e emerge como fundamento da existência humana em sua concreticidade históricocultural em um processo que converge para impedir a sua sujeição

\footnotetext{
3 “A verdade religiosa, disse Kierkegaard, é pessoal, não apenas proposicional. É uma experiência que propicia o relacionamento vivo com o Deus vivo. Nesse sentido, a verdade religiosa é muito mais que o que sabemos; é o que vivemos. Não é apenas verdade para ser dominada pelos cristãos; ela os domina." (GEISLER, 2002, p. 334-335, grifos meus)
} 
às verdades objetivas ${ }^{4}$ enquanto conteúdos que sob a acepção de dados que se mantém em condição de exterioridade são incutidos no indivíduo ${ }^{5}$. Dessa forma, atribuindo à ironia a possibilidade de exercício e desenvolvimento da liberdade subjetiva, Kierkegaard sublinha a negatividade absoluta como característica do referido processo em Sócrates, conferindo relevância a sua experiência através de um novo sentido, que encerra os principais elementos do seu pensamento (tais como maiêutica, ignorância, aporia, entre outros) e implica a construção de uma perspectiva que torna independente o agente em um movimento de oposição ao modus vivendi da sociedade que tende à negação de sua vida histórico-cultural e da influência dos costumes ou tradições que condicionam atitudes e comportamentos e impedem a realização da individualidade em seu absoluto e irredutível valor.

Com Fichte, a subjetividade se tornara livre, de maneira infinita e negativa. Mas para sair deste movimento da ausência de conteúdo, em que se movia em infinita abstração, ela precisava ser negada; para que o pensamento pudesse ser real, precisava tornar-se concreto. Com isso se destaca a questão da realidade metafísica. Este princípio fichtiano, de que a subjetividade, o eu, tem validade constitutiva e é o único onipotente, conquistou Schlegel e Tieck, e a parti daí eles operaram ao nível do mundo. Disto resultou uma dupla dificuldade. Em primeiro lugar, confundiu-se o eu empírico e finito com o Eu eterno; em segundo lugar, confundiu-se a realidade metafísica com a realidade histórica. Aplicouse assim sem mais nem menos um ponto de vista metafísico incompleto

4 Nesta perspectiva, cabe sublinhar que "a eternidade e infinitude de Deus são ao mesmo tempo absolutamente reais e absolutamente incompreensíveis. Por isso, não se pode propriamente 'falar de Deus', isto é, formular uma teologia. A teologia é uma objetivação de Deus, assim como a dialética é uma objetivação do mundo.” (MORA, 2004a, p. 1645)

5 "Então, suposto que tudo esteja em ordem com relação às Sagradas Escrituras - e daí? Alguém então que não tinha a fé chegou agora um único passo mais perto da fé? Não, nem um único. Pois a fé não resulta de uma deliberação científica direta, e nem chega diretamente; ao contrário, perde-se nessa objetividade aquela atitude de interesse infinito, pessoal e apaixonado, que é a condição da fé, o ubique et nusquam [lat.: por toda parte e em nenhum lugar] através da qual a fé pode nascer. Aquele que tinha a fé ganhou alguma coisa em relação ao poder e à força da fé? Não, nem um tiquinho: nesse conhecimento prolixo, nessa certeza que paira à porta da fé e suspira por ela, ele está antes numa posição tão perigosa que vai precisar de muito esforço, muito temor e tremor para não cair na tentação, e confundir conhecimento com fé. Enquanto que até agora a fé teve na incerteza um pedagogo proveitoso, ela deveria ter seu inimigo na certeza. De fato, se se exclui a paixão, a fé deixa de existir, e certeza e paixão não se atrelam juntas." (KIERKEGAARD, 2013, p. 35) 
à realidade. Fichte queria construir o mundo; mas o que ele tinha em mente era um construir sistemático. Schlegel e Tieck queriam inventar um mundo. (KIERKEGAARD, 1991, p. 237-238, grifos do autor)

Baseado no princípio que afirma a validade constitutiva da subjetividade, cuja perspectiva, caracterizando o eu como único onipotente, emerge da filosofia do eu absoluto e da liberdade de Fichte, os românticos (Schlegel e Tieck) interpretam a ironia como a possibilidade de negação da realidade histórica em sua totalidade, convergindo para as fronteiras que encerram a invenção de um mundo através do estabelecimento de uma realidade autoproduzida em um processo que guarda correspondência com o ideal de "viver poeticamente", consistindo na capacidade do indivíduo de autocriação em um movimento que se sobrepõe aos elementos factuais da existência e atribui a condição de ficção à história.

Concebendo a realidade histórica sob a acepção que envolve um dom e uma tarefa, Kierkegaard sublinha o tipo de relação que se desenvolve entre a realidade e o sujeito ${ }^{6}$, que encerra a existência de um passado que reclama validade e a capacidade do agente de realização da realidade efetiva em um processo que demanda integração, responsabilidade e respeito concernente às consequências racionais implicadas, convergindo para se opor ao ironista romântico, que não reconhece a validade relativa da realidade histórica e circunscreve a sua realidade ao caráter de possibilidade somente através de um movimento que assinala uma concepção de ironia totalizante, detentora de uma liberdade infinita e um poder ilimitado de autocriação que culmina na pretensão de construção da própria identidade de si e do cenário de sua atuação segundo o princípio de elaboração dos elementos que se conjugam para a constituição de um personagem e do seu contexto em uma obra ficcional em detrimento do ambiente histórico-social concreto e dos valores, práticas e condutas que o determinam e formam um

\footnotetext{
6 “A realidade é - para Kierkegaard - a concretização ética do espírito ou a sua liberdade efetiva, pela qual a consistência metafísica do ser é determinada. No entanto, esta realidade pessoal nunca é dada imediatamente e deve ser sempre alcançada de forma reflexiva, através de um desenvolvimento dialético e sintético, que coincide com a criação continuada do eu." (BINETTI, 2005, p. 9, grifos meus)
} 
arcabouço que não é passível de eliminação absoluta mas requer, em suma, integração e superação.

Nesta perspectiva, afirmando a irrevogabilidade de determinados fatos da existência, tal qual a condição do homem como um ser criado por Deus e sob esta égide dependente do Criador e portador de um propósito em sua existência, Kierkegaard distingue o exercício de criarse (poeticamente) e o movimento de deixar-se criar (poeticamente), que caracteriza o cristão e permanece atrelado a um contexto dado determinadamente em um processo que demanda a adaptação do indivíduo, sobrepondo-se ao ironista romântico que no ato de autocriação poetiza seu mundo circundante em uma construção que suspende a moral e a vida ética, instaurando um modo hipotético e subjuntivo de existir que converge para a perda de toda continuidade da sua vida e a sua redução a meras disposições afetivas, consistindo o tédio ${ }^{7}$ a sua única continuidade.

Opondo-se à ironia romântica e ao seu caráter totalizante, Kierkegaard defende o valor da ironia dominada para a vida pessoal, comparando-a com a condição fundamental que exerce a dúvida em relação à ciência em um processo em que "viver poeticamente" implica orientação e integração concernente ao tempo da existência individual em um movimento que encerra liberdade positiva em face da realidade histórica, convergindo para as fronteiras que envolvem uma ironia como um fenômeno imobilizado na selvagem infinitude cuja limitação se impõe para conferir a sua prática uma justa significação, a sua verdadeira validade, na medida em que finitiza, restringe, atribuindo, dessa forma, verdade, realidade, conteúdo, em uma construção que alcança sustentação e consistência através da disciplina e da punição, configurando o início absoluto da vida pessoal ${ }^{8}$.

7 "Tédio, esta eternidade sem conteúdo, esta felicidade sem gozo, esta profundidade superficial, esta saciedade faminta." (KIERKEGAARD, 1991, p. 246)

8 "Quem simplesmente não compreende a ironia, quem não tem ouvidos para seus sussurros, carece eo ipso daquilo que se poderia chamar o início absoluto da vida pessoal, carece daquilo que em certos momentos é indispensável para a vida pessoal, carece do banho de renovação e de rejuvenescimento, do banho de purificação, que salva a alma de ter a sua vida na finitude, mesmo que viva aí com força e energia; ele não conhece o frescor e a força que se encontram quando, sentindo o ar pesado demais, nos despimos e nos atiramos ao mar da ironia, naturalmente não para aí permanecermos, mas para tornarmos a nos vestir saudáveis e alegres e leves.” (KIERKEGAARD, 1991, p. 277, grifos do autor) 


\section{Do saber como interioridade e o processo de descoberta do universal da ética em si próprio: tornar-se subjetivo como transformação do sujeito em si mesmo}

Excluindo qualquer possibilidade da emergência da verdade através da exterioridade do indivíduo, Sócrates concebe a dimensão externa como parte constitutiva da sua interioridade e pressupõe que a verdade objetiva exige o exercício da racionalidade e da reflexão crítica, o que implica uma unidade envolvendo o universal interior e o universal exterior em um processo que não circunscreve a subjetividade às fronteiras da contingência e da particularidade mas atribui à esfera subjetiva a condição que encerra a interioridade universal do pensamento.

Estabelecendo uma analogia envolvendo o Oráculo de Delfos e o seu caráter objetivo e o oráculo daimônico e a sua condição de interioridade, Hegel sublinha a liberdade subjetiva que a perspectiva de Sócrates instaura em um movimento que encerra uma forma transicional da moralidade objetiva para a moralidade subjetiva, haja vista que o dáimon emerge entre a externalidade do oráculo e a interioridade do indivíduo, sobrepondo-se à vontade subjetiva e a sua inclinação, convergindo para um processo que confere ao homem enquanto indivíduo concreto o direito de exercer a sua racionalidade e a sua capacidade crítica diante da imposição de valores e práticas, condutas e comportamentos constitutivos do legado histórico-cultural.

Os homens que não alcançaram a profundidade da consciência de si, que não transitaram da ingênua unidade substancial à existência para si, ainda não tinham o poder de desvendar a decisão na interioridade do mundo humano. Pode-se ver no demônio de Sócrates o início do movimento que levaria a vontade a deslocar-se do além para si mesma e a conhecer-se no interior de si mesma. É o início da liberdade consciente $e$, portanto, verdadeira. A real liberdade da ideia, que é o que dá a cada um dos momentos da razão a sua realidade própria, presente e consciente, também e, por conseguinte, o que atribui à atividade de uma consciência a certeza suprema ao determinar-se a si mesma, quer dizer, a culminância do conceito da vontade. Mas esta última determinação de si só pode pertencer ao domínio da liberdade humana quando se encontra na posição de uma culminância em si mesma isolada e superior a toda a particularidade e a toda a condição. Só assim ela será de acordo com o seu conceito. (HEGEL, 1997, § 279, p. 259, grifos do autor) 
Baseado em uma concepção do saber como interioridade, tendo em vista o seu caráter essencialmente reflexivo em um processo que converge para a descoberta do universal da ética em si próprio, a expressão "conhece-te a ti mesmo" escapa a qualquer tipo de introspecção de ordem psicológica e individual e encerra o sentido que implica a impossibilidade de que a verdade seja transmitida a partir da exterioridade, à medida que, segundo Sócrates, a ciência moral e as suas premissas guardam correspondência com conceitos universais cuja constituição impõe-se por intermédio da indução, capacitando o indivíduo a se sobrepor à contingência e à particularidade e a assumir práticas e valores, condutas e comportamentos compatíveis com a razão em um movimento que resulta em um saber que correlaciona o "poderfazer" e o "dever-fazer" e se sobrepõe a sua contradição.

Nesta perspectiva, sobrepondo-se a sua particularidade contingente, o que se impõe é tornar-se subjetivo em um processo que implica o exercício de uma dúvida intensa e a necessidade de guardar fidelidade em relação a si próprio em proveito daquilo que pensa, condição de sua independência como tal, haja vista que a continuidade absoluta escapa ao exercício do pensamento, convergindo para a sua impossibilidade de superar-se a si mesmo no afirmativo. A condição de superioridade em relação ao real, atribuída pelo pensamento de Kierkegaard à subjetividade, converge para a impossibilidade de uma avaliação envolvendo ambas as dimensões através de uma medida comum em um processo que encerra uma tensão inaplacável entre existência e transcendência e que implica o paradoxo de uma concepção que assinala que, embora o existente seja um sujeito pensante, a existência recusase, em suma, ao pensamento ${ }^{9}$, haja vista que existir não se reduz a um objeto de saber mas consiste em tomar consciência da sua existência em um movimento que abrange simultaneamente a eternidade e o devir.

Contrapondo-se à dissolução da existência humana nas fronteiras da pura conceituação intelectual, Kierkegaard impõe à dialética objetiva de Hegel e ao seu caráter especulativo e conciliador que visa à dimensão

9 Nesta perspectiva, convém salientar que, segundo Kierkegaard, "a existência não depende da essência, como se a primeira fosse uma especificação da segunda. A essência é ideal; por isso, é pensável e definível. A existência não é ideal, mas real; por isso é indefinível e, em alguma medida, não pensável. Se a existência fosse definível, não seria existência, porém essência." (MORA, 2004a, p. 1644) 
lógico-histórica, guardando a tendência de suprimir o indivíduo e a sua liberdade, a dialética subjetiva, que converge para um movimento que implica três formas de vivência pessoal, a saber, estética, ética e religiosa, que consistem em diferentes possibilidades existenciais fundamentais ${ }^{10}$. Dessa forma, à sujeição da existência humana e do seu caráter concreto à vida própria das ideias e aos seus conceitos racionais, Kierkegaard impõe à escolha um papel fundamental concernente à definição de uma forma de vida em um processo que encerra várias possibilidades e escapa à sua compreensão, não havendo nenhum tipo de fundamento lógico mas dependendo apenas do exercício do seu querer.

A novidade introduzida por Kierkegaard em relação à compreensão e classificação da verdade no âmbito filosófico é original, uma vez que a verdade deixa de ser um fundamento lógico e adquire o estatuto da apropriação existencial e relacional. Existencial, pois é o indivíduo singular que a reduplica no movimento de concretizar a si mesmo, por isso a tese de que a verdade só existe se ela faz vida no interior de quem, agindo, a produz. E relacional, porque substancialmente a verdade, na ótica do pensador dinamarquês, é Jesus Cristo encarnado na mais profunda subjetividade (a fé é uma determinação da subjetividade) do existente e que se deixa apropriar mediante a relação e unicamente através da relação. (ALMEIDA; VALLS, 2007, p. 56, grifos meus)

Um acontecimento que guarda possibilidade de emergir como fundamento da existência humana em sua concreticidade históricocultural no sentido que implica os seus limites, quais sejam, tanto a vida como a morte, eis o que se impõe à verdade, segundo a concepção de Kierkegaard, que atribui à experiência de sua apropriação a condição que envolve a paixão da interioridade em um processo que encerra a necessidade de superação do desespero diante da incerteza objetiva na medida em que assinala que existir não se reduz a um objeto de saber mas consiste em tomar consciência da sua existência em um movimento que abrange simultaneamente a eternidade e o "devir".

\footnotetext{
10 "Kierkegaard distingue assim três estádios existenciais: o estádio estético em que o homem se abandona à imediatidade, o estádio ético em que se submete à lei moral ou geral como se diz, e o estádio religioso em que o homem, abraçando a eternidade se deixa dirigir pelo amor, para além do bem e do mal." (FARAGO, 2006, p. 120)
} 
Nessa perspectiva, contrapondo-se à dissolução da existência humana nas fronteiras da pura conceituação intelectual, Kierkegaard atribui à subjetividade uma condição que escapa à vida própria das ideias e aos seus conceitos racionais, ao pensamento, em suma, em um processo que envolve o paradoxo que encerra uma crise irredutível entre existência e transcendência na medida em que a existência não se dispõe ao pensamento, a despeito de que o ser existente consiste em um sujeito pensante em um movimento que implica a interioridade e guarda correspondência com a necessidade de tornar-se subjetivo, tendo em vista que a verdade implica, em última instância, a transformação do sujeito em si mesmo. Dessa forma, assinalando o absoluto e irredutivel valor do indivíduo em um movimento que sublinha a relação envolvendo a sua subjetividade e circunscreve a possibilidade do conhecimento às fronteiras da consciência de si, Kierkegaard opõe-se à caracterização do saber como bem absoluto em uma construção que tende não à busca da verdade mas antes à procura de um centro para a vida, afirmando que a verdade é a subjetividade ${ }^{l l}$ e que o seu elemento é a interioridade através de um processo que escapa às fronteiras que encerram o irracionalismo e o relativismo e converge para a incerteza objetiva.

Opondo-se à dialética objetiva e ao seu caráter especulativo e conciliador que visa à dimensão lógico-histórica e tende à supressão do indivíduo e da sua liberdade, o pensamento de Kierkegaard identifica a verdade como um acontecimento que transpõe as fronteiras que encerram o saber, emergindo como uma questão existencial em um movimento que atribui à subjetividade a possibilidade de instauração de uma relação dialética que implica a paixão que, trazendo a fé como o seu ápice, converge para uma experiência que atrela o conhecimento de si à descoberta do sentido da existência.

A fé é a mais alta paixão de todo homem. Talvez haja muitos homens de cada geração que não a alcancem, mas nenhum vai além dela. Se se encontram ou não muitos homens do nosso tempo que não a descobrem, não posso decidi-lo, porque apenas me é lícita a referência a mim próprio, e não devo ocultar que me resta ainda muito que fazer, sem por isso

11 “Contra o que afirmava Hegel, não há equivalência entre o ser e a razão, a realidade e o pensamento. A verdade não é o 'puro pensamento': a verdade é a subjetividade.” (MORA, 2004a, p. 1644) 
desejar trair-me, ou trair a grandeza, reduzindo isto a um assunto sem importância, a uma doença infantil, de que se espera estar curado o mais depressa possível. (KIERKEGAARD, 1979, p. 185, grifos meus)

Verdade como paradoxo ${ }^{12}$, eis o que se impõe à verdade subjetiva enquanto um acontecimento que demanda uma relação de interioridade que se sobrepõe ao caráter objetivado que exclui o cume da expressão da subjetividade, a paixão, e se contrapõe à concepção que encerra a "objetividade" do pensamento e da vida em um modo especulativo que tende a uma reflexão baseada na lógica sistemática racionalista e científica, convergindo a perspectiva de Kierkegaard para as fronteiras que encerram um devir que recusa a possibilidade de uma mediação ou uma "síntese", na medida em que defende que a verdade está em movimento em um processo no qual o existente singular em sua interioridade impõe-se ao "como" da sua linguagem, que emerge como a abertura da vivência em sua paixão do infinito que, consistindo na sua subjetividade, constitui-se a própria verdade, impedindo a sua sujeição às verdades objetivas enquanto conteúdos que sob a acepção de dados que se mantém em condição de exterioridade são incutidos no indivíduo. Conclusão: "Para a reflexão objetiva, a verdade se torna algo objetivo, um objeto, e aí se trata de abstrair o sujeito; para a reflexão subjetiva, a verdade se torna apropriação, a interioridade, a subjetividade, e aí se trata justamente de, existindo, aprofundar-se na subjetividade" (KIERKEGAARD, 2013, p. 202, grifos meus).

\section{Conhecimento e conversão da alma entre o martírio socrático e o desespero fáustico e angústia e desespero na transição do ético ao religioso}

$O$ toque de despertar não é dado primordialmente pela inteligência, mas por um sentimento: o sentimento da angústia. O ser humano é abalado

12 "Explicar o paradoxo significaria assim compreender mais profundamente o que é um paradoxo e que o paradoxo é o paradoxo. Deus é uma representação suprema que não se pode explicar por algo diferente, mas somente pelo fato de aprofundar-se a si mesmo nesta representação. Os mais altos princípios de todo pensamento não podem ser provados senão indiretamente. Suponhamos que o paradoxo seja assim o limite para a relação de um ser existente com uma verdade eterna essencial, então o paradoxo não poderá ademais ser explicado por algo diferente se a explicação deve ser válida para seres existentes." (KIERKEGAARD, 2001, p. 248) 
pelo sentimento desta carência inexplicável cujo efeito está em nos desterrar radicalmente. $\mathrm{Na}$ angústia nos é revelado a precariedade de nossa condição original, o estado inato de faticidade em que estamos. (BEAUFRET, 1976, p. 24)

A equivalência envolvendo conhecimento e conversão da alma, eis o que se impõe à perspectiva de Sócrates que, baseada no princípio "conhece-te a ti mesmo", guarda correspondência com as fronteiras que encerram a concepção do saber como interioridade e o primado atribuído à questão ética em um processo que torna o conhecimento não apenas o sentido último do exercício filosófico mas da própria existência, tendo em vista a noção acerca da necessidade de constituição de uma ciência moral através de raciocínios indutivos capazes de formar conceitos universais (como a coragem, a justiça, entre outros), à medida que circunscreve o mal à ignorância de si em um movimento no qual a ignorância de si emerge como um saber.

Nessa perspectiva, se a verdade não é passível de transmissão ou ensino a partir da exterioridade do indivíduo na medida em que atribui ao saber um caráter essencialmente reflexivo, guardando correspondência com a ação de concentrar-se em si através de um movimento que escapa ao sentido de uma introspecção de ordem psicológica e individual e tende às fronteiras que encerram a descoberta do universal em si, a arte do diálogo socrático implica a possibilidade de libertação do sujeito através de um processo que envolve a consciência do seu pseudo-saber e a superação da ignorância, que resulta do confronto de ideias e conceitos em uma relação cujas implicações são desenvolvidas e submetidas à prova, convergindo para a emergência de elementos incompatíveis e estruturas contraditórias que se conjugam em uma construção que tem a pretensão de definir uma realidade material ou imaterial, o que implica a conclusão de que as consequências do raciocínio não se impõem senão pelas opiniões particulares e pelo condicionamento das paixões.

Dessa forma, convergindo para a constituição do saber verdadeiro em um processo que demanda a superação das particularidades através de uma reflexão crítica que desestrutura o arcabouço das crenças, dogmas e axiomas existentes, o diálogo socrático encerra o conhecimento de si e implica a descoberta do universal e o consenso 
acerca da verdade e do bem em uma construção que, sobrepondo-se às fronteiras que envolvem as opiniões e as suas paixões determinantes, objetiva o aperfeiçoamento do homem enquanto indivíduo concreto e cidadão, tendo em vista a concepção acerca da necessidade de dedicação ao exercício da temperança como prerrogativa para uma conduta de justiça, capaz de se sobrepor aos interesses particulares e que implica o respeito pela igualdade e pela reciprocidade.

Correlacionando o exercício filosófico e a ética e a política, o diálogo socrático implica o despertamento crítico através do princípio da razão negativa caracterizado pela ironia em um processo interrogativo baseado na consciência da ignorância que converge para um exame, uma avaliação que se impõe mais aos próprios homens em sua individualidade e subjetividade do que em relação as suas ideias ou noções da realidade em um movimento que tende à manifestação da sua natureza através da exposição dos seus pensamentos e atos, convergindo para a perturbação da ordem de conhecimento e ação existente na medida em que, no tocante à constituição da realidade e à compreensão do mundo, detém a possibilidade de colocar em questão e pôr em crise a estabilidade sociocultural e o arcabouço paradigmático de ideias e valores, normas ou regras, sobrepondo-se ao poder institucionalizado em uma construção que não se restringe à esfera intelectual mas supõe o desafio da mudança, a transformação.

Nessa perspectiva, se o princípio da dúvida impõe-se ao exercício da autonomia e à determinação da verdade através dos próprios recursos cognitivos e capacidade intelectual em um processo que questiona crenças, dogmas e axiomas, instaurando o pensamento filosófico moderno e a necessidade de aplicação de um método que possibilite a construção do conhecimento, este, emergindo como mediato (discursivo), ou seja, indireto, guarda correspondência com um processo, transmitindo a ideia de uma série de atos que objetiva alcançar a realidade das coisas e dos objetos ideais, proporcionando, enfim, a definição do seu conceito, que, em suma, dependendo do grau de abstração que o envolve, impõe, de modo correspondente, o distanciamento do sujeito diante da realidade concreta, artifício que se torna fundamental enquanto possibilidade de transcendência, convergindo para produzir a alienação do homem em sua 
individualidade em relação ao contexto histórico-cultural e políticosocial, conforme os casos de Sócrates e Fausto, cujas figuras, exemplos paradigmáticos da existência moderna, incorporam a negatividade que acarreta, no caso do primeiro, a ruptura entre o homem e o Estado, e, no caso do segundo, a cisão entre o homem e a religião, em um movimento que atribui primazia ao indivíduo e a sua subjetividade e implica dor e sofrimento: o martírio socrático e o desespero fáustico.

O indivíduo, que sai do geral por opção, só retorna em relação absoluta com o absoluto. Ética, nessa visão, é equivalente de coletivo. Isso significa soma de indivíduos e, no caso, de indivíduos que pecam. Abraão, embora mortal e falho, não se torna indivíduo pecando, no caso, contra a ética. Abraão é o eleito de Deus. Para Silentio, o demônio socrático, por exemplo, reside fora do geral e o indivíduo está fora do geral por circunstâncias, não por sua culpa. Há um ponto de semelhança entre a eleição de Deus por Abraão e a ordem que Sócrates recebe do oráculo, ainda que Sócrates possua o seu demônio interior.

$\mathrm{O}$ indivíduo que, na visão de nosso autor, quer salvar o geral com seu mistério e seu silêncio é um incrédulo (como Fausto de Goethe) ou irônico (como Sócrates). Para Silentio, a ironia é a superioridade do subjetivo sobre o objetivo; esta posição é exatamente oposta ao que acreditava Hegel. Logo, Abraão pode ser admirado, mas não entendido (...). (PAULA, 2008, p. 6, grifos do autor)

À impossibilidade da suspensão teleológica da moral que, circunscrevendo-se à instância do geral, demanda do homem em sua individualidade concreta uma conduta que se lhe corresponda em um movimento baseado na racionalidade que o caracteriza, impõe-se o paradoxo que emerge da relação com o Absoluto, que sobrepõese à referida instância e torna o dever absoluto, conforme defende Kierkegaard que, nessa perspectiva, opõe o sacrifício de Abraão, o "herói da fé", ao sacrifício de Agamêmnon, o "herói trágico", que imola a sua filha Ifigênia no interesse da cidade e para o bem da coletividade em um comportamento cuja manifestação guarda raízes na instância do geral ${ }^{13}$, sublinhando que se no caso do "herói trágico" o objeto do

13 "De acordo com os Cantos Cíprios, poemas que narram fatos anteriores à Ilíada, os Aqueus, ignorando as vias de acesso para Tróia, abordaram em Mísia, na Ásia Menor e, depois de diversos combates esparsos, foram dispersados por uma tempestade, regressando cada um a seu reino. Oito anos mais tarde, reuniram-se novamente em Áulis. O mar, todavia, permaneceu inacessível aos navegantes por causa de uma grande calmaria. 
dever é o seu único desejo em uma relação que implica a renúncia ao desejo em função do dever, no exemplo do "herói da fé" há uma identificação entre desejo e dever em um processo que demanda a renúncia a ambos, transcendendo a sua atitude o arcabouço da moral que, com os seus códigos, normas e regras, é relegado à condição de uma instância relativa.

O verdadeiro herói trágico sacrifica-se ao geral com tudo o que lhe é próprio: os seus atos, todos os seus impulsos pertencem ao geral; está manifesto e nessa manifestação é o filho bem amado de ética. A sua situação não se aplica a Abraão, que nada fez pelo geral e permanece no secreto. Estamos então em presença do paradoxo. Ou o Indivíduo pode, como tal, estar em relação absoluta com o absoluto, e nesse caso a moralidade não é o supremo estádio, ou então Abraão está perdido; não é um herói nem trágico nem estético. Nestas condições pode parecer que nada é mais fácil do que o paradoxo. Torna-se-me então necessário repetir que, se cremos nisso firmemente, não se é cavaleiro da fé, porque a única legitimação concebível é a tribulação e a angústia, ainda que não se lhe possa dar uma acepção geral, porque então suprime-se o paradoxo. (KIERKEGAARD, 1979, p. 178-179, grifos meus)

Caracterizando-se como um fenômeno que guarda oposição à razão e ao bom senso, a fé de Abraão se sobrepõe às regras ou normas instituídas, convergindo para um movimento que desde a sua origem emerge destituído de lógica, à medida que não há sentido em crer na própria possibilidade de uma ordem divina desse tipo, o que implica o grau de dificuldade envolvido no conteúdo da mensagem e na condição do seu emissor, qual seja, o Absoluto, em um processo que encerra como fundamento a relação entre o humano e o divino. Perder a razão e, consequentemente, a dimensão de existência com a qual mantém liames irredutíveis no processo de constituição da realidade objetiva, eis o que se impõe à fé corporificada por Abraão diante da determinação divina da total aniquilação daquilo que representava o seu mundo finito,

Consultado mais uma vez, Calcas explicou que o fato se devia à cólera de Ártemis, porque Agamêmnon, matando uma corça, afirmara que nem a deusa o faria melhor que ele. A cólera de Ártemis poderia se dever também a Atreu, que, como se viu, não lhe sacrificara o carneiro de velo de ouro ou ainda porque o rei de Micenas prometera sacrificar-lhe o produto mais belo do ano, que, por fatalidade, havia sido sua filha Ifigênia. Agamêmnon, após alguma relutância, terminou por consentir no sacrifício de Ifigênia, ou por ambição pessoal, ou por visar ao bem comum." (BRANDÃO, 1986, p. 86-87) 
a saber, Isaque, por intermédio do qual o sentido da sua vida estava assegurado, haja vista o papel destinado a cumprir como herdeiro do patriarca hebreu.

Depois dessas coisas, pôs Deus Abraão à prova e lhe disse: Abraão! Este lhe respondeu: Eis-me aqui!

Acrescentou Deus: Toma teu filho, teu único filho, Isaque, a quem amas, e vai-te à terra de Moriá; oferece-o ali em holocausto, sobre um dos montes, que eu te mostrarei.

Levantou-se, pois, Abraão de madrugada e, tendo preparado o seu jumento, tomou consigo dois dos seus servos e a Isaque, seu filho; rachou lenha para o holocausto e foi para o lugar que Deus lhe havia indicado. (BÍBLIA DE ESTUDO DE GENEBRA, Gênesis, 22, 1-3, 1999, p. 40)

Angústia, eis o que se impõe à contradição envolvendo as perspectivas moral e religiosa encarnada por Abraão diante da ordem de Deus em referência ao seu filho, Isaque, em um processo que guarda possibilidade de não se circunscrever a um sacrifício mas caracterizar-se como um ato de um indivíduo execrável ou até mesmo de um louco, convergindo para as fronteiras que encerram a fé como uma relação absoluta com o Absoluto, segundo Kierkegaard, que atribui a sua experiência a condição de uma incerteza absoluta e mantém o seu exercício sob a égide que envolve temor e tremor, tendo em vista o paradoxo que crer implica em um movimento cuja dimensão emerge como o desafio do desespero.

Opondo-se à concepção de um fenômeno que ocupa o lugar do saber na ausência de certeza ou uma escolha racional exercida em relação ao futuro, a fé atribui à angústia um valor educativo absoluto em um processo que envolve o desnudamento das ilusões do mundo finito através da corrosão de todas as suas coisas, convergindo o exercício de crer para a única forma de vida capaz de superar o desespero que, consistindo no sintoma da "posse" da eternidade em si, demanda que o indivíduo torne-se a "Exceção" ou o "Escândalo", tal qual Abraão ${ }^{14}$, que acredita

\footnotetext{
14 "Se bem que o sacrifício de Abraão se assemelhe a todos os sacrifícios de recém-nascidos do mundo antigo, a diferença entre ambos é total. Se nas culturas primitivas um tal sacrifício, não obstante seu caráter religioso, era exclusivamente um hábito, um rito, cuja significação se tornava perfeitamente inteligível, no caso de Abraão é um ato de fé. O Patriarca não compreende por que um tal sacrifício lhe é imposto, mas ele se dispõe a fazê-lo, porque o Senhor o exigiu. Por este ato, aparentemente absurdo, Abraão inaugura uma nova experiência religiosa: a substituição de gestos arquetípicos por uma religião implantada na fé." (BRANDÃO, 1986, p. 93, grifos do autor)
} 
em virtude do absurdo no paradoxo absoluto que implica a intrusão do Eterno no temporal através da ordem de Deus para sacrificar o seu filho em um movimento que assinala que a autenticidade da existência guarda correspondência com a condição verdadeiramente religiosa de um sujeito capaz de desesperar, não consentindo com a possibilidade da fuga mas procurando a verdade nas profundezas dessa experiência.

A angústia pode ser comparada à vertigem. Quando o olhar imerge num abismo, existe uma vertigem, que nos chega tanto do olhar como do abismo, visto que não seria impossível deixar de encarar. Esta é a angústia, vertigem da liberdade, que surge quando, ao desejar, o espírito, estabelecer a síntese, a liberdade imerge o olhar no abismo das suas possibilidades e agarra-se à finitude para não soçobrar. (KIERKEGAARD, 1968, p. 66)

A pretensão de escapar à angústia converge para uma condição que envolve possibilidades existenciais que encerram a procura do sentido ou a busca do Absoluto na imanência, como o movimento do sujeito que vive no instante do prazer sensual em sua fruição de si próprio e em detrimento de tudo o que caracteriza-se pela banalidade, pela insignificância e pela mesquinhez em um comportamento complacente que, em busca da felicidade, tende a evitar a monotonia que envolve a repetição, que configura a atitude estética ${ }^{15}$ e traz como símbolo Don Juan, a encarnação do sedutor, e tem como destino o tédio e, consequentemente, o desespero, ou como na conduta ética ou moral ${ }^{16}$, que implica a consonância do indivíduo e da sua subjetividade com o princípio geral do bem e do mal em um processo cuja integração traz como fundamento a repetição representada pelas escolhas que a vida

15 "Aquele que vive esteticamente espera tudo de fora. Daí a angústia enfermiça com que muita gente fala do que há de terrível no fato de não ter encontrado seu lugar no mundo. A angústia demonstra sempre que o indivíduo espera tudo desse lugar, nada de si mesmo." (KIERKEGAARD, 2001, p. 131)

16 "A pessoa ética tem seu centro em si mesma, não fora de si. Enquanto a pessoa estética esquece de si, a pessoa ética tenta esquecer tudo, exceto ela mesma. A pessoa ética escolhe a si mesma em seu valor eterno. No ético, a repetição torna-se uma possibilidade, já que se é ao universal e, continuamente, se torna atitude com pensamento no eterno. O esteta identifica a felicidade humana com prazer. O ético identifica a felicidade humana como uma realização de uma tarefa obrigatória, tão essencialmente relacionada à personalidade, a ponto de ser imanente a ela, sendo nada mais nada menos que a realização do seu verdadeiro e dado 'eu'." (GOUVÊA. 2006, p. 260) 
no âmbito de uma organização social requer para a manutenção de uma "boa consciência" e que envolvem desde a atividade profissional até a constituição familiar, que consistem em expressões do ethos de uma determinada comunidade. Dessa forma, expondo a condição humana e a ruptura envolvendo o ético e o religioso, Kierkegaard defende a necessidade do salto qualitativo entre ambos os estádios de existência ${ }^{17}$ em um movimento que, sobrepondo-se à possibilidade de reconciliação dos contrários, demanda a radicalização do paradoxo, a saber, a fé, que não representa para o existente singular qualquer solução geral em um processo no qual o ato de crer converge, na referida transição, para as fronteiras que não perfazem senão a experiência do abandono do $E u$ à Transcendência.

Peca o Indivíduo que reivindica a sua individualidade frente ao geral, e não pode reconciliar-se com ele senão reconhecendo-o. De cada vez que o Indivíduo, depois de ter entrado no geral, se sente inclinado a reivindicar a sua individualidade, entra numa crise da qual só poderá libertar-se pela via do arrependimento e abandonando-se, como Indivíduo, no geral. Se tal é o fim supremo destinado ao homem e à sua vida, a moralidade participa então da mesma natureza da eterna felicidade do homem, a qual constitui em cada momento, e para toda a eternidade, o seu telos porque haveria contradição em afirmar-se que ela pode ser abandonada (quer dizer, teleologicamente suspensa), visto que, desde o momento em que se suspendeu, está perdida, enquanto que estar suspenso não significa perder-se, mas conservar-se na esfera superior que é o seu telos. (KIERKEGAARD, 1979, p. 141)

Nesta perspectiva, sobrepondo o indivíduo singular ao universal, a fé consiste em um fenômeno que guarda raízes na interioridade humana em um movimento que encerra a impossibilidade de sua tradução em uma linguagem que se impõe através de universais, convergindo para as fronteiras que atribui à condição de crer uma essencial contraditoriedade e

17 "Cada um dos estágios é um modo de ser da existência humana (modo de ser além disso 'escolhido' pelo sujeito e com o qual este 'se compromete'). Como o estágio ético parece a negação do estético e o religioso a negação do ético, pode-se pensar que nos encontramos perante uma tríade de caráter hegeliano regida por leis dialéticas. Ora, mesmo que, em sua oposição ao hegelianismo, Kierkegaard tenha absorvido deste mais do que ele mesmo acreditava, deve-se reconhecer que a tríade em questão é dialética num sentido não idêntico ao hegeliano. Por um lado, trata-se de escolha e não de determinação racional. Por outro lado, não há síntese no sentido hegeliano.” (MORA, 2004a, p. 1644) 
absurdez, haja vista o caráter paradoxal que distingue o seu exercício que, prescindindo de razoabilidade e de uma natureza objetiva e discursiva, não é passível de comunicação, circunscrevendo-se a uma experiência subjetiva, conforme expõe a suspensão teleológica do ético exemplificada pelo caso de Abraão e a sua relação com o Absoluto diante da ordem que implica o sacrifício de seu filho em um processo que encarna a transição do ético ao religioso através de um salto qualitativo que não assinala senão a possibilidade de superação da ética e da lei ${ }^{18}$.

Então por que é que o fez Abraão? Por amor a Deus, como, de maneira absolutamente idêntica, por amor de si mesmo. Por amor de Deus porque este exige essa prova de fé; e por amor de si mesmo para dar a prova. É por isso que ele me aterroriza ao mesmo tempo que suscita a minha admiração. Aquele que se renega a si próprio e se sacrifica ao dever renuncia ao finito para alcançar o infinito. (KIERKEGAARD, 1979, p. 144-145, grifos meus)

\section{Aspectos Conclusivos}

Uma tarefa para a vida, eis o que se impõe ao trabalho de Kierkegaard que, guardando correspondência com o pensamento de Sócrates, converge para a afirmação da subjetividade em face da objetividade através da ironia em um processo que se sobrepõe à sua expressão romântica e torna a questão da existência individual o centro da sua reflexão, o que implica a consideração sobre o seu caráter trágico e a tematização da angústia como a vertigem da possibilidade da liberdade em um movimento que encerra o desespero como uma experiência fundamental que demanda o desafio do paradoxo absoluto representado pela fé, que "é uma promessa de liberdade ilimitada e de possibilidades infinitas que um saber racional não pode propiciar" (FARAGO, 2005, p. 204).

Nessa perspectiva, baseado na negatividade absoluta que emerge da ironia socrática, Kierkegaard opõe-se à conciliação da dialética

18 Convém destacar a diferença radical que há em relação ao princípio que, baseado na suposta ilimitada liberdade religiosa, professa atos ilegais ou imorais, determinando a conduta e as práticas do assassino ou do terrorista moderno, que em função de suas crenças explicam as suas ações, justificando as suas motivações e defendendo-as em nome de Deus e da Religião em detrimento da lei, das normas do Estado e da sociedade. 
especulativa e a supressão da experiência individual e da subjetividade em um processo que tende a atribuir caráter extremo ao paradoxo ${ }^{19}$ e a manter sob a égide da inexequibilidade a conciliação dos opostos como um movimento próprio de uma existência autêntica, encerrando uma concepção que se sobrepõe ao saber como bem absoluto e prescinde de uma elaboração positiva da verdade, procurando um ponto de convergência para a vida em uma construção que atrela a verdade à subjetividade, à medida que circunscreve a sua constituição como tal às fronteiras da interioridade através do fenômeno da apropriação, que traz como fundamento a paixão e recusa-se a exprimir-se em termos de uma estrutura capaz de transmitir segurança plena e total, e que, longe de subestimar o pensamento, a linguagem e a racionalidade, convergindo para o relativismo, consiste, em última instância, na incerteza objetiva.

Todas as formas de especulação supostamente "imparciais", não obstante o seu aparente rigor e seu pretenso heroísmo sublime, bem longe de serem tudo isso, não são mais do que uma espécie de desumana curiosidade. Ousarmos ser nós próprios, ousarmos ser indivíduos, não um qualquer, mas este que somos, só em face de Deus, isolado na imensidade do esforço e da responsabilidade, é este o desafio do existencialismo kirkegaardiano. (GILLES, 1971, p. 11)

Contrapondo-se ao devir lógico-metafísico que emerge da perspectiva de Hegel e converge para uma transição que escapa à ruptura em um movimento que implica a mediação que encerra a possibilidade de conciliação da oposição, Kierkegaard defende o caráter essencial do salto qualitativo em um processo que envolve os estádios no caminho da vida e as suas mudanças, constituindo-se um fenômeno fundamental em relação à transposição das fronteiras do ético para o religioso concernente à existência individual ${ }^{20}$.

19 Dessa forma, torna-se relevante esclarecer que o recurso ao termo em questão assinala que se "os problemas podem ser resolvidos mediante 'sínteses' à feição hegeliana; os paradoxos só podem ser enfrentados por meio da escolha irremediável de 'um ou outro'." (MORA, 2004a, p. 1644, grifos meus)

20 Cabe sublinhar a correspondência que guarda a noção de situação com a filosofia da existência em um processo que assinala que "tal conceito foi elaborado por diversas tendências filosóficas, mas especialmente por aquelas que, desde a reação anti-hegeliana, tentaram considerar o real como algo diferente de uma 'objetividade' que não se decide a incluir o sujeito mesmo como elemento seu ou como âmbito dentro do qual se dá - sem prejuízo 
"Se o homem não tivesse consciência da possibilidade, se não tivesse espírito e inteligência, ele não conheceria a angústia, de onde se conclui que a angústia está ligada à espiritualidade do homem. Em consequência disso, é então impossível libertar-se da angústia quanto de si mesmo" (LE BLANC, 2003, p. 83). Dessa forma, ao caráter trágico da existência impõe-se uma angústia fundamental que, sobrepondo-se ao medo e a qualquer tipo de fenômeno que permaneça atrelado a algo propriamente objetivo, guarda correspondência com a vertigem da possibilidade da liberdade, convergindo para a culpabilidade e pressupondo o erro original, o que implica a necessidade de que o homem em sua individualidade concreta vivencie diferentes possibilidades existenciais em um movimento que encerra a experiência de um processo de fuga que, em suma, tem como fundamento o próprio ser que através da atitude estética e da conduta ética ou moral pretende alcançar o sentido ou o Absoluto que apenas no estádio religioso há possibilidade de encontrar.

Nesta perspectiva, se a atitude estética implica a fruição da subjetividade consigo própria no instante do prazer sensual, a conduta ética ou moral encerra a sua harmonização com a generalidade do bem e do mal em um processo que envolve a escolha do bem e a integração à comunidade através de um movimento baseado na repetição, que emerge como a realidade e a seriedade da vida e determina o destino segundo a "boa consciência", convergindo para as fronteiras que tornam ambas as situações comportamentais incapazes de promover o encontro do sentido ou do Absoluto, haja vista que escapa à imanência a possibilidade de superação da desordem existencial, consistindo o estádio religioso ${ }^{21}$ a única condição que tende à descoberta de um significado para a angústia.

de sua 'verdade' - a realidade objetiva". Dessa forma, alcança relevância o pensamento de Kierkegaard na elaboração de uma filosofia "situacionista", que encerra a emergência do homem como um "ser em situação": "Essa situação pode ser autêntica - como ocorre no 'estádio religioso' ou' decisionista' - ou inautêntica - como ocorre no 'estádio estético' ou 'contemplativo'." (MORA, 2004b, p. 2710)

21 "A existência religiosa inclui a existência ética, é certo, tanto quanto inclui a existência estética, mas ela transcende estas categorias, e é precisamente por isso que ela pode abrangê-la, pois ao mesmo tempo ela as purifica, relativiza e destrona. 'Prosseguindo de um estágio para outro estágio, os limites anteriores não são simplesmente deixados para trás, como degraus numa escada, mas são absorvidos e relativizados'." (GOUVÊA, 2006, p. 262) 
A fé é o ardor íntimo totalmente irredutível a uma crença que vai desfiando seus complementos de objetos diretos destinados à exterioridade onde o Espírito permanece estranho a si mesmo. A certeza interior, certeza existencial, não objetiva, é própria da fé que é precompreensão ao conceitual da própria lei do devir da criatura. A fé é paixão perseverante da existência no tempo. Vivificando a nossa condição de liberdade em devir no tempo, a irrupção do eterno no tempo abre o futuro para o existente em sua paixão, em sua paciência, em sua perseverança. (FARAGO, 2005, p. 173)

Dessa forma, recorrendo ao exemplo de Abraão e a sua experiência envolvendo Deus e a exigência para sacrificar o seu único filho, Isaque, em um movimento que encerra a oposição entre a finitude e a infinitude, Kierkegaard assinala a crise existencial que implica o princípio moral e a ordem divina, mostrando que ao caráter inconciliável entre o ético e o religioso impõe-se um salto qualitativo que converge para a dimensão de um desafio do desespero, a saber, a fé, que acena com uma salvação que, longe de contribuir para a reconciliação dos contrários, tende à radicalização do paradoxo, em um processo que atribui a autenticidade ao indivíduo que sob a tensão inaplacável entre existência e transcendência escolhe a experiência que não representa um substituto do saber em face da ausência de certeza nem tampouco uma decisão racional no tocante ao porvir mas a relação absoluta com o Absoluto, diante de cujo paradoxo absoluto ${ }^{22}$, a emergência do "Deus-Homem" 23 e a ruptura na ordem do ser e do tempo, cabe ao sujeito abandonar o seu Eu à Transcendência, amando o seu "mistério essencial" e transformando-se, enfim, em si mesmo.

22 “Este é o 'paradoxo absoluto': o de um Deus encarnado na história e que sempre ultrapassa a história." (MORA, 2004a, p. 1645)

23 "A possibilidade do escândalo é de tal forma inseparável da fé que se o Deus-Homem não fosse esta possibilidade, não poderia também ser objeto da fé. A possibilidade do escândalo, passada na fé e assimilada por ela, é assim o caráter negativo do Deus-Homem. Pois, sem a possibilidade do escândalo, ter-se-ia então o reconhecimento direto e o Deus-Homem seria um ídolo. O reconhecimento direto é paganismo. Vê-se quanto se desmereceu o cristianismo eliminando-se a possibilidade do escândalo. Vê-se como se faz dele um paganismo amável e sentimental.” (KIERKEGAARD, 1979, p. 312) 


\section{Referências}

ALMEIDA, Jorge M.; VALLS, Álvaro L. M. Kierkegaard. Rio de Janeiro: Jorge Zahar, 2007.

BEAUFRET, Jean. Introdução às filosofias da existência: de Kierkegaard a Heidegger. Tradução de Salma Tannus Muchail. São Paulo: Duas Cidades, 1976.

BÍBLIA DE ESTUDO DE GENEBRA. Gênesis. Tradução de João Ferreira de Almeida. Revista e Atualizada. São Paulo / Barueri: Cultura Cristã / Sociedade Bíblica do Brasil, 1999.

BINETTI, María J. La posibilidad necesaria de la libertad. Un análisis del pensamiento de Søren Kierkegaard. Pamplona/Spain: Cuadernos de Anuario Filosófico (Serie Universitaria, 177), 2005.

BRANDÃO, Junito de Souza. Mitologia grega. Volume I. Petrópolis / RJ: 1986.

FARAGO, France. Compreender Kierkegaard. São Paulo: Vozes, 2005.

GEISLER, Norman L. Enciclopédia de apologética: respostas aos críticos da fé cristã. Tradução de Lailah de Noronha. São Paulo: Editora Vida, 2002.

GILLES, Thomas Ranson. História do Existencialismo e da Fenomenologia. São Paulo: EPU - Editora da Universidade de São Paulo, 1971.

GOUVÊA, Ricardo Q. Paixão pelo Paradoxo. Uma Introdução a Kierkegaard. São Paulo: Fonte Editorial, 2006.

HEGEL, Georg Wilhelm Friedrich. Princípios da filosofia do direito. Tradução de Orlando Vitorino. São Paulo: Martins Fontes, 1997.

KIERKEGAARD, Søren Aabye. Diário de um sedutor; Tremor e Temor; O Desespero humano. Traduções de Carlos Grifo, Maria José Marinho, Adolfo Casais Monteiro. São Paulo: Abril Cultural, 1979.

KIERKEGAARD, Sören Aabye. O conceito de angústia. Tradução de Torrieri Guimarães. São Paulo: Hemus, 1968.

KIERKEGAARD, Søren Aabye. O conceito de ironia. Constantemente referido a Sócrates. Tradução de Álvaro Luiz Montenegro Valls. Petrópolis / RJ: Vozes, 1991.

KIERKEGAARD, Søren Aabye. Pós-Escrito às Migalhas Filosóficas. Tradução de Álvaro Luiz Montenegro Valls e Marília Murta de Almeida. Vol. I. Petrópolis / RJ: Vozes, 2013.

KIERKEGAARD, Søren Aabye. Textos selecionados. Tradução de Ernani Reichmann. Reimpressão. Curitiba: UFPR, 2001. 
LE BLANC, Charles. Kierkegaard. Tradução de Marina Appenzeller. São Paulo: Estação Liberdade, 2003.

MORA, José Ferrater. Dicionário de filosofia. Tomo III (K-P). Tradução de Maria Stela Gonçalves et al. 2. ed. São Paulo: Loyola, 2004a.

MORA, José Ferrater. Dicionário de filosofia. Tomo IV (Q-Z). Tradução de Maria Stela Gonçalves et al. 2. ed. São Paulo: Loyola, 2004b.

PAULA, Marcio Gimenes. O silêncio de Abraão: os desafios para a ética em Temor e Tremor de Kierkegaard. Interações - Cultura e Comunidade, Belo Horizonte / MG, v. 3, n. 4, p. 55-72, 2008. 